Studia Anglica Posnaniensia 50/4, 2015

doi: 10.1515/stap-2015-0033

\title{
LITERATURE
}

\section{“... THE RUINS OF EUROPE IN BACK OF ME.” JAN KLATA'S SHAKESPEARE AND THE EUROPEAN CONDITION}

\author{
MAGDALENA CIEŚLAK ${ }^{1}$
}

University of Łódź

\begin{abstract}
Jan Klata's Shakespearean productions are famous for his liberal attitude to the text, innovative sets and locations, and a strong contemporary context. His 2004 H., a Teatr Wybrzeże production performed in the Gdańsk Shipyard, reaches to the Polish history of the eighties (the importance of Solidarity and the fall of communism) to comment on the state of the democratic Poland twenty years later. The 2012 Titus Andronicus, a coproduction of Teatr Polski in Wrocław and Staatsschauspiel Dresden, explores the impact of historical traumas on national prejudice and relations within the new Europe. The 2013 Hamlet with Schauspielhaus Bochum again tries to diagnose the contemporary condition and is again deeply rooted in a specific geopolitical context.

Discussing both Titus Andronicus and Hamlet, I would like to explore Klata's formula of working with Shakespeare. Primarily, he takes advantage of the fact that Shakespeare's texts are not simply source texts but hypertexts with multiple layers of meanings accumulated over the centuries of circulation, production and adaptation. Perhaps similarly to Heiner Müller, whose plays he willingly incorporates in his productions, Klata anatomizes the plays and then radically reconstructs them using other texts, literary and paraliterary. What Klata eventually puts on stage is a hybrid that is rooted in the Shakespearean hypertexts but also heavily draws from historical, cultural and political contexts, and that is relevant to him as the director and to the particular specificities of the venues, theatres and companies he works with.

The hybridized and contextualized Shakespeare becomes for Klata a way to comment on current issues that he sees as vital, like dealing with the burden of the past, confronting the reality of the present, or understanding and expressing national identity, problems that are at once universal and specific for a person living in the EU in the twenty first century.
\end{abstract}

Keywords: Jan Klata, European Shakespeare, intercultural dialogue, heteroglossia, Heiner Müller, Hamlet, Titus Andronicus

$1 \quad$ Corresponding author: Magdalena Cieślak (mcieslak@uni.lodz.pl), Institute of English Studies, Department of Drama and pre-1800 British Literature, University of Łódź, ul. Pomorska 171/173, 90-236 Łódź, Poland. 
In a 2013 interview for the Polish magazine Wysokie Obcasy, Michał Gieleta, a Polish-born theatre director based in the UK, educated in Oxford and trained by Franco Zeffirelli, offered an interesting comment on a major difference between the methods of British and Polish theatre directors. Gieleta claimed that Central Europe is dominated by "Regietheater," essentially standing for "directorial megainterpretation" and "barbaric intervention in the text," which he juxtaposed with the British respect for the intellectual property of the author. He further said: "Editing a text is a delicate matter .... It takes a scalpel in the hands of a professional. A lumberjack's maniacal axe won't do." His comment is especially valid in relation to Shakespeare's texts. Non-English speaking theatre directors by necessity deal with a translation, a text that by definition has been interpreted and hence altered by a third party. English-speaking directors, in turn, have to deal with another necessity - to respect "the letter" of Shakespeare. From the point of view of theatrical experience, this may lead to two drastically different disappointments - going to a "British" Shakespeare and listening to what we already know by heart, or going to a "vernacular" Shakespeare and being dissatisfied with the translation. A different kind of experience happened to me at the 2014 Shakespeare Festival in Gdańsk: I watched Jan Klata's production of Hamlet in (mainly) German, Polish and English, with Polish and English surtitles. It was a Hamlet that I did not know by heart; a Hamlet that liberated me from the impositions of the text; a Hamlet that took me by surprise; a Hamlet that offered new meanings; a Hamlet that made me think of a European experience.

Karin Beier's 1995 multilingual production of A Midsummer Night's Dream presented a new way of looking at the central problem of the play - the inability to effectively communicate. ${ }^{2}$ Language barriers hindered the dialogues of the play's conflicted couples (like the English-speaking Hippolita/Titania and the Italian-speaking Theseus/Oberon, or the Italian-speaking Helena and the Hungarian-speaking Demetrius), and highlighted the anarchistic chaos "governing" the mechanicals' rehearsals. The overriding principle of the performance's heteroglossia served to stress language confusion and lack of communication rather than to explore the ability to reach an understanding and form coherent politics in spite of language and culture differences. The scene of the mechanicals' rehearsal (1.2) perhaps best reflected it: each of them was trying to push through their own theatrical tradition, the Russian Starveling advocating Stanislavsky's and the Polish Bottom voicing Grotowski's methods, the German Flute insisting on introducing Brecht's alienating devices, and the Bulgarian Snout as a mime silently gliding in front of the quarrelling anti-ensemble.

2 For interesting analyses of heteroglossia in Beier's productions (of A Midsummer Night's Dream and the subsequent 1997 The Tempest) see Carlson (2006: 156-158) and Guntner (2006: 163-168). 
Carlson claims that Beier's projects reflect "the postmodernist acceptance of, indeed glorification of, difference and discontinuity" (2006: 159). Klata's multilingual productions are of a different nature. They use linguistic and cultural diversities not as a source of miscommunication, ${ }^{3}$ but as a platform for international dialogues, dialogues which are born from conflicts of the past and which explore the tensions of the present, but which also provide a sense of continuity. Through the medium of theatre - the experience of actors working together and of various audiences watching the productions in different places - those dialogues and tensions can lead to an understanding and can help to see Europe and the world as a place for a shared experience not in spite of but in its diversity. ${ }^{4}$

Klata's approach to European Shakespeare has changed over time. His 2004 $H .{ }^{5}$ performed in the Gdańsk Shipyard was inherently Polish, heavy with references to Polish national history ${ }^{6}$ but also commenting on the newly forming Polish identity within the European Union. ${ }^{7}$ Titus Andronicus (2012), ${ }^{8}$ a coproduction of Teatr Polski in Wrocław and Staatsschauspiel Dresden, at first appeared to be simply a Polish-German production, with a clear-cut dialectic division - Romans were played by German-speaking actors, and Goths by Polish actors. But this dichotomy was not so straightforward. Lavinia, for example, though largely mute throughout the performance, was played by a Polish actress

3 Although that happens as well. In Titus Andronicus, for example, linguistic misunderstandings are often used for comic effect, alongside cultural prejudices and stereotypes (see Mancewicz 2015).

$4 \quad$ It is also important to mark the difference between productions such as Klata's Hamlet or Titus Andronicus, which use symbolic locations, situations, characters and events to explore (inter)national traumas of European history, or the crises of the present social and media life, and more specific and clearly diagnostic, but in a way less "European" enterprises, such as Catherine Grosvenor's and Lorne Campbell's Cherry Blossom. This 2008 project of Traverse Theatre in Edinburgh and Teatr Polski in Bydgoszcz traced the particular ordeals of Polish immigration to Scotland. For a very interesting analysis of Cherry Blossom see Schreiber (2012)

5 The whole performance, without subtitles, can be watched at the website of the National Audiovisual Institute: http://www.nina.gov.pl/instytut/projekty/rejestracja-wydarze\% C5\%84/artyku\%C5\%82/2011/06/29/h_-w-rezyserii-jana-klaty (accessed 10 March 2015); it is also available on DVD in Polish with English subtitles from Polskie Wydawnictwo Audiowizualne.

6 The most significant factor was the location of the production, the Gdańsk Shipyard, where the Polish Solidarity movement was born. Another crucial element was the fact that Hamlet's father appeared as a Hussar, a voice of the glory of Poland's combatant past. For an extended discussion on $H$. in comparison with Klata's 2013 Hamlet see Kizelbach (2015).

$7 \quad H$. premiered on July 2, 2004; only two months after Poland had joined the EU. Claudius, for example, can be seen as a new type of politician insisting on a peaceful resolution of the conflict with Fortinbras, and showing off his cosmopolitan knowledge of French wine.

8 A trailer of the production can be viewed at: https://www.youtube.com/watch?v=D-nf14trdQ (accessed 12 April 2015). For interesting reviews of the production see Mancewicz (2015) and Cinpoeş (2015). 
(Paulina Chapko), while two German-speaking actors, Wolfgang Michalek (Titus) and Stefko Hanushevsky (Saturninus), were Austrian. Thus, the very idea of a neat translation of the Roman/Goth conflict into a German/Polish one should be approached less schematically. ${ }^{9}$

Titus Andronicus was called "an international cooperation" that explored the traumas of WWII (Mrozek 2012). The cooperating institutions, Teatr Polski in Wrocław and Staatsschauspiel in Dresden - can indeed be associated with a historical burden. Wrocław/Festung Breslau, German at that time, was destroyed by the Red Army during one of the last battles of WWII (February May 1945), while Dresden was heavily bombed in February 1945 by the Allied Forces (RAF and USAAF), which resulted in firestorms that completely destroyed the city centre. As Mrozek puts it, "what divides those cities is $250 \mathrm{~km}$, the border on the Lusatian Neisse, and the memory of the people". Klata's production, however, may indicate that the memory of the people from the cities that shared a similar historical trauma but then followed very different trajectories could be a connecting element. As the Wrocław and Dresden theatres were working together, uncompromisingly exploiting national stereotypes and frequently cracking jokes around them, audiences had to rethink their own national and historical prejudice.

In Klata's Titus Andronicus, the Polish-German antagonism rooted in the experience of the war became a foundation for observations on the current shape of that relationship, while the present state of affairs provided a springboard for a discussion on national stereotypes in the era of economic migration within the EU. The production was thus an "an exercise in sensitivity, memory and prejudice" (Mrozek 2012) organized around the principle of artifice and exaggeration, and done with the help of Heiner Müller's Anatomy Titus Fall of Rome: A Shakespeare Commentary.

Artifice and exaggeration became tools that exposed the mechanisms of stereotyping and prejudice. Romans/Germans - composed and civilized - were a reflection of how the Germans tend to be perceived, not only by Poles. Goths/Poles, in turn, were a typical image of Polish immigrants (Kaczorowski 2015) popular not only among Germans but also the British, who when faced with the post-2004 wave of Polish immigration, had to confront their old and new prejudices: Polish men were loud, vulgar and primitive, while Polish wom-

9 Although linguistically the German/Polish division was very clear-cut, it was based on language, not nationality. In an interview after the Gdańsk Festival performance (see Works Cited for the link) the term "German actors" turned out to be problematic and Klata specifically explained that the German-speaking actors were not all German. In the context of national stereotypes and historical memory, so vital in the production, that issue should be seen as meaningful. 
en sensual and sexually available. ${ }^{10}$ This stereotyping strategy was most visible in the way Klata showed Aaron. Aaron was played by a white man crudely painted black, wearing buffalo-like horns on his forehead and a huge penis attached to his crotch. So grotesquely overdone, Aaron became the archetypal devil illustrating how "stereotypes deform the truth," as Kaczorowski puts it. Mrozek similarly notices that Aaron was "the embodiment of racist fears and phantasies", an image blown out of proportion, distorted and fuelled by irrational emotions. That consistent strategy of hyperbolization, sometimes to a controversial level of ridiculousness, stressed the fact that the production did not offer a realistic comment on truth and facts but rather a stylized vision of the exaggerated images, fears and ideas that for various reasons people hold on to.

An important addition to the production were fragments of the 1985 Anatomy Titus Fall of Rome: A Shakespeare Commentary, a play that is often seen as Müller's vision of a European crisis. For Müller, this play is about "the Third World invading the First World" (2000a: 183). ${ }^{11}$ The dynamic of the relations between Goths and Romans illustrates the mechanism of the fear of the Other, ${ }^{12}$ and Lucius's words "A Goth is a Nigger is a Jew" (Müller 2000a: 179) show that logic very well. Kaczorowski notes that Klata followed Müller's reading of Goths as "Jews, Gypsies, and Muslims" - as communities that have been marginalized or stigmatized in contemporary Europe - and that by showing Poles as the new "Goths" he made a point about Western Europe "threatened with waves of immigrants". However, in the production those ideas functioned only symbolically. The "Nigger," the "Jew", Poles and Germans were caricatures of stereotypes that keep plaguing the cultural landscape of the European existence, which is precisely what Klata confronted the audiences with.

Asked to moderate the Q\&A session after the Gdańsk Festival performance of Titus (August 2013), Małgorzata Grzegorzewska started with what she called a "provocative question": "To what extent," she wondered, "the production would

10 It must be noticed, however, that such a stereotype would be more typical for the 1990s. After 2004, with a new wave of legitimate Polish immigration to other countries, specifically to the UK, a different image of a Pole started to form - a hard working professional, either a construction worker or a plumber for men, and a blond, slim and educated "nice wife material" for women. The stereotype of an excessively sexualized East European girl was interestingly explored in the presentation of Tamora. She appeared sitting on an ice-cube, which with deliberate crudeness pointed to her status as both a hot and insatiable sexual predator and an object of desire. In the already mentioned interview after the Gdańsk Festival performance, Ewa Skibińska, the actress playing Tamora, admitted that she was tempted to perform without her underwear on, but eventually decided not to.

11 Except for fragments from Hamletmachine, other quotations from Müller, including fragments of Anatomy Titus Fall of Rome: A Shakespeare Commentary, are my translations.

12 A similar mechanism can be seen also in the recent events related to the Syrian fugitives, specifically in the exaggerated and fear-fuelled negative reactions towards them that are observable across Europe. 
be understood outside of the Polish-German dialogue". She referred specifically to the overt jokes that could only be understood in reference to what she called "the cultural competence" contextualized in the relationship of those two cultures. Responding, Klata questioned the very concept of cultural competence, and suggested that each audience member could form their own relation with the performance. This view was promptly confirmed by an opinion of one audience member, an American who admitted that while "the whole cultural and linguistic layer of the performance passed over him," he remained heavily affected by the images.

Klata then made another strong point saying that artists - directors and actors - were not the producers of Coca-Cola aiming to make a beverage that would be loved all over the world. He stressed that he did not wish to make universal art for everyone's tastes; he made performances that worked and made sense in his immediate surroundings. He claimed that in theatre, people $(=\mathrm{ac}-$ tors, directors) communicated with people (= audiences) through their own artistic language, a system of associations and references that each of us had.

The following year Klata directed Hamlet ${ }^{13}$ in the Schauspielhaus Bochum ${ }^{14}$ with the support of the Polish Institute in Düsseldorf. Paraphrasing Gieleta's comment on editing texts one could say that for this production Klata used "a lumberjack's maniacal axe," but he used it with surgical precision. This production was done in fact in three languages - German, Polish and English. The text of Hamlet was in a German translation that mixed the traditional Schlegel/Tieck translation with a modernized rendition by Zadek and Greiffenhagen. At the Gdańsk Shakespeare Festival, the text was accompanied by surtitles in Polish and English. What opened the production was an "arch-German" text - Heiner Müller's Hamletmachine - and what finished it was an "arch-Polish" text Zbigniew Herbert's "The Elegy of Fortinbras". ${ }^{15}$ Herbert's poem was recited in Polish by Fortinbras (played by Marcin Czarnik ${ }^{16}$ ) and was translated live into

13 A trailer of the production can be viewed at: https://www.youtube.com/watch? $\mathrm{v}=$ Bp7pC0Wuqs (accessed 10 April 2015). Fragments of the following section on Klata's Hamlet come from my review of the production for ReviewingShakespeare.

14 My thanks to Lawrence Guntner for making me aware of the fact that Bochum was the site of Peter Zadek's famous Hamlet from 1977. How acutely aware Klata was of that production could be seen in many cross-references, such as the choice of translation or props, e.g. pig masks (in the Mousetrap sequence Rosencrantz and Guildenstern appeared in pig masks, which alluded to the pig masks used in several scenes in Zadek's Hamlet - cf. Canaris 1980).

15 In a pre-premiere interview available as an MP3 in Cöllen, Klata calls those two texts that open and close the production "a very German one" and "a very Polish one", respectively. An English translation of Herbert's poem is available at http://www.poemhunter.com/bestpoems/zbigniew-herbert/elegy-of-fortinbras/ (accessed 20 March 2015).

16 Czarnik played Hamlet in Klata's $2004 \mathrm{H}$. In the 2013 Hamlet he first played Ghost and then Fortinbras. As Ghost Czarnik spoke German; notably, he began the performance with the opening lines of Müller's Hamletmachine. 
German by Horatio. Another fragment of Hamletmachine appeared in the scene of Ophelia's madness (4.5). Instead of singing songs, Ophelia said, in German: "I am Ophelia. The one the river didn't keep. The woman dangling from the rope. The woman with her arteries cut open. The woman with the overdose. SNOW ON HER LIPS ...” (Müller 2000b: 212).

A German play at the beginning, a Polish poem at the end, and an English play in German with Polish and English surtitles in the middle, did not exhaust the cultural and linguistic interrelations of the production. Sometimes the characters spoke English. In the play within the play sequence (3.2), for example, Claudius, sitting with Gertrude in the audience in the balcony, commented on Hamlet's performance in English. His fluent English was contrasted with Gertrude's infantile attempts to first say something in English, and then to produce some Polish words and swearwords. ${ }^{17}$

In Hamlet intercultural dialogues and relations between the past and present were explored on a different plane than in Titus Andronicus - primarily through references to the theatrical and literary traditions, as well as through cultural quotations and intertextualities. ${ }^{18}$ Polish theatre audiences were very likely to recognize Marcin Czarnik from $H$.; especially that he appeared, both as Ghost and Fortinbras, in the fencing suit that was the trademark of $H$. Zadek's Hamlet was quoted in various ways, through the text and props. Most notably, in 5.1 Dimitrij Schaad as Hamlet appeared in a red coat which, as Barbara Cöllen notes, was the same coat in which Urlich Wildgruber performed Hamlet in Zadek's 1977 production. The second part of Mousetrap - a long sequence of "pure form" when Hamlet, Rosencrantz and Guildenstern were spraying each other with paint, dancing and making obscene gestures to Bach's music evoked Jürgen Gosch's 2005 Macbeth staged in Düsseldorf (Keim 2015, Kizelbach 2015). The diamond-coated skull that Hamlet took from the gravediggers echoed Damien Hirst's artwork, and also brought to mind disco balls, ${ }^{19}$ an association strengthened by Klata's emblematic use of $80 \mathrm{~s}$ and 90 s pop music. In the opening sequence, over a hundred books fell from above with a loud thump and remained on stage for the rest of the performance for people to walk on, roll

17 The audience in Gdańsk reacted with laughter to Gertrude's clumsy Polish, especially when she produced one of the most popular swearwords, taught to any foreigner arriving in Poland. I see this little episode as Klata's typical comment on cultural stereotyping: this swearword has become a trademark of the Polish language, used so frequently that it is believed to be recognized nearly anywhere, and is one of the first words in Polish that a foreigner is likely to learn.

18 The fact that not all quotations or references would be clear for all audiences did not change the centrality of the citational strategy in this production.

19 In June 2007, at an after show party, Damien Hirst had a disco ball skull. See a short clip showing the skull at: https://www.youtube.com/watch?v=6vu3c57PmTE (accessed 15 April 2015). 
over on, read, and make Ophelia's grave. Finally, the typically self-referential subplot of the arrival of the players was translated into a very interesting Mousetrap sequence in which the theatrical paratext overshadowed even the cultural weight of the "to be or not to be" soliloquy.

The Mousetrap sequence consisted of two parts. In the first, Hamlet appeared alone and delivered the "to be or not to be" speech from 3.1. He did it flatly and emotionlessly, reciting as if it were a school performance. Claudius and Gertrude offered him encouraging comments. Gertrude was much impressed by the fact that Hamlet had managed to memorize such a lengthy piece, while Claudius offered a quasi-professional evaluation of Hamlet's performance, praising his balanced acting but also criticizing some aspects of his delivery. ${ }^{20}$ This was also an occasion for Claudius to comment on the different traditions in Polish and German theatres. He mentioned, for example, the Polish practice of a kick in the buttocks for good luck, treating it as a highly amusing anecdote. Then Hamlet announced the second part of the show, explaining that this time it will be less about content and more about form. At this point Rosencrantz and Guildenstern appeared wearing underwear and pig masks; they covered the floor with a drop cloth and brought forth buckets of a mud-like substance and tubes of paint. They splashed each other with paint, dancing frantically to Bach's music. When they took bottles of brown paint and started squeezing it out from between their buttocks into each other's faces, Claudius interrupted the performance. Furious, he came on stage ranting about the desecration of art, and shouted that "shit art"/"Scheisskunst" was passé, and that it was outrageous to do such stuff to Bach's music. Claudius's outburst became a criticism of current traditions, and this voice so clearly insisted on separating the sacred from the profane that it might have been understood as an echo of accusations and abuse addressed at Klata for his To Damascus in Teatr Stary in Kraków. ${ }^{21}$

With this Hamlet, Klata revisited literary and cultural artefacts, and danced a new dance on the graves and ashes of past Hamlets, Shakespeares, books, and

20 Kizelbach (2015: 156) makes a very interesting remark, noticing that Claudius's condescending manner made him resemble Simon Cowell in The X Factor. Her review also offers an extended comment on how in the Mousetrap sequence Klata addressed the theatrical tradition.

21 When Klata was appointed the director of the Teatr Stary in Kraków, a cultural institution perceived as the home of Polish national theatre and the epitome of Polish culture and tradition, there were some strong reactions from right-wing Kraków activists and theatre goers. His production of Strindberg's To Damascus was boycotted by several audience members who protested against having the national stage "profaned". The protests continued for some time, and Klata was strongly attacked in the media by a group defending the tradition of the national stage. He was not fired and continues to be the director of the theatre. Although Hamlet premiered before To Damascus, viewers watching Hamlet after the "Damascus scandal" in November 2013 might eagerly make the connection. 
theatrical traditions, confronting the iconic text with his own set of associations and references. As in Titus Andronicus, he again presented audiences with his artistic language and relied on their individual readings of it. Naturally, as always in the world of literacy, the more you recognized the more fun you had. My thrill at identifying Hamletmachine in the first lines of the production was partly the thrill of a person who did their homework. In the end, however, when in the closing sequence Fortinbras/Ghost/Hamlet from $H$. was conversing with the dead Hamlet through Herbert's poem (more homework done), and the roof in the Gdańsk Shakespeare Theatre, where I saw the production, opened to the stars in the sky above, the thrill was different. It was the excitement of a rich theatrical experience, packed with codes, references and footnotes to be thought over and deciphered afterwards (new homework to do).

Critics often draw attention to the provocative or controversial quality of Klata's productions. More importantly, however, those productions, using Klata's distinctive language, address the audience's own language of historical and cultural associations and references. Through such confrontations we are eventually encouraged to do still more homework - re-evaluate our systems of beliefs.

In $H$. Klata confronted the Polish present and the promise of the future with the past. His Shakespearean characters were like Poles in 2004. Feeling themselves a part of Europe and eager to catch up with its standards, they could be seen as the new Europeans - aspiring golf players and amateur sommeliers, partying in the ruins of the movement that made accession to the EU possible. In Titus Andronicus the confrontation took a wider circle. It was rooted in the intense Polish-German historical and cultural dialogue, but reached beyond simple next-door neighbour animosities. By focusing on national stereotypes, cultural prejudice, and the discrimination of certain (not necessarily minority) communities, the production dealt with the reality of the EU. Additionally, the linguistic layer of the production touched upon communication problems within Europe, where each nationality speaks their own language and yet strives for a successful dialogue. Hamlet, similarly, diagnosed our reality, but communication seemed easier because the production centred on culture and media. Since many speak English (or Shakespeare), know Bach and pop music of the 80s and $90 \mathrm{~s}$ - these being international cultural passports for people from both sides of the Iron Curtain - national stereotypes become less significant as intercultural dialogues grow more and more media oriented.

In his interview after the performance of Titus Andronicus at the Gdańsk Festival, Klata said that his plays were not global products, or "Europroducts", designed to appeal to a larger audience through their universal quality. And yet, I see them as more than just local co-productions relying on the audience's "cultural competence" and ability to recognize history, stereotypes and cultural 
prejudice. Although it is true that they resonate very strongly with audiences who can make immediate connections with their historical, national and cultural references, those productions are not just glocalized Shakespeares. In fact, their impact can be seen in what is opposite to glocalization. Using local issues - like the Polish political situation in H., Polish-German historical tensions in Titus Andronicus, or local literary and theatrical traditions in Hamlet - they extend the discussion into wider contexts that equally powerfully resonate with audiences of various cultural or national backgrounds.

In that sense, Klata's productions offer a potentially optimistic view of communication in Europe and the world. In a cathartic way, Klata draws from the past and present traumas, conflicts, anxieties and diversities to point to the similarity of experiences across cultures, and thus pushes audiences towards understanding. His theatrical language - a rich network of associations, references, and intertextualities - may be very individual but turns out to be common, or at least intuitively accessible, for a lot of people. At a time when Europe is experiencing a difficult period, when nationalistic and conservative parties are taking over various Member States, a voice like Klata's is particularly important. His is a voice that neither shies away from digging out historical issues that often still hover over our reality, nor glosses over the cultural, linguistic and political tensions that define our times. ${ }^{22}$ But through Shakespeare and theatre he shows that it is possible to use that "burden" constructively, and that diversity fuels more than fear and prejudice - it is the ground on which our future may be built.

\section{REFERENCES}

Canaris, Volker. 1980. Peter Zadek and Hamlet. Transl. Brigitte Kueppers. The Drama Review: TDR 24(1). 53-62. MIT Press. http://hamletguide.com/stage/pdf/zadek.pdf (accessed 10 March 2015).

Carlson, Marvin. 2006. Speaking in tongues. Language at play in the theatre. University of Michigan Press.

Chojnowski, Grzegorz. 2012. Ave Klata! (Review of Titus Andronicus). http://chojnowski. blogspot.com/2012/09/tytus-andronikus-teatr-polski-we.html (accessed 12 April 2015).

22 In his recent Shakespearean production, King Lear in Teatr Stary in Kraków, Klata uses the environment of the Catholic Church, its mysticism, hierarchical structure, and problematic legacy, to discuss the problem of both divine authority, which is ultimate and indisputable, and human authority, which is corruptible and frail. Both the issue of legitimacy of authority and the legacy of Christianity in the Western world are powerful and difficult discussion topics right now. 
Cieślak, Magdalena. 2015. Review of Hamlet by Jan Klata. ReviewingShakespeare. http://bloggingshakespeare.com/reviewing-shakespeare/hamlet-schauspielhausbochum-gdansk-poland-2014/ (accessed 20 April 2015).

Cinpoeş, Nicoleta. 2015. Titus Andronicus by Teatr Polski, and Titus Andronicus by Hiraeth Artistic Productions (review). Shakespeare Bulletin 33(1). 135-141.

Cöllen, Barbara. 2013. Jan Klata pokazał Niemcom w Bochum krzykliwego i szokującego Hamleta [Jan Klata showed the German audience a loud and shocking Hamlet]. Deutsche Welle (11 March 2013). http://www.dw.de/jan-klata-pokaza\%C5\%82-niemcom-w-bochumkrzykliwego-i-szokuj\%C4\%85cego-hamleta/a-16664425 (accessed 20 April 2015).

Festiwal Szekspirowski. Spotkanie po spektaklu Tytus Andronicus J. Klaty [The Shakespeare Festival - a meeting after the performance of J. Klata's Titus Andronicus] (6 August 2013). https://www.youtube.com/watch?v=w061fdjikPg (accessed 12 April 2015).

Gieleta, Michał. 2013. Michał Gieleta: Nie obraziłem się na polski teatr (wywiad) [I didn't take offence with the Polish theatre. An interview]. Wysokie Obcasy (19 April 2013). http://www.wysokieobcasy.pl/wysokie-obcasy/1,53668,13686392,Michal_

Gieleta_Nie_obrazilem_sie_na_polski_teatr.html (accessed 14 April 2015).

Guntner, Lawrence. 2006. From Elsinore to Brussels: Shakespeare as Translational Discourse on the German Stage. In Sukanta Chaudhuri \& Chee Seng Lim (eds.), Shakespeare without English: The reception of Shakespeare in non-anglophone countries, 156-176. Dorling Kindersley (India) Pvt. Ltd.

Kaczorowski, Tomasz. 2015. Bea von Malchus show i Tytus w rytmie disco [Bea von Malchus show and Tytus disco style] (21 August 2013). http://tomaszkaczorowski. blogspot.com/2013/08/shake-lear-rez-bea-von-malchus-tytus.html (accessed 14 April 2015).

Keim, Stefan. 2015. Ophelia liebt Barren-Bondage. Nachtkritik.de. http://www.nachtkritik.de/ index.php?option=com_content\&view=article\&id=7848:hamlet-jan-klata-inszeniertshakespeares-am-bochumer-schauspielhaus-im-stil-einer-graphicnovel\&catid=91: schauspielhaus-bochum\&Itemid=100190 (accessed 24 April 2015).

Kizelbach, Urszula. 2015. Review of Hamlet by Jan Klata. Multicultural Shakespeare. 12. 155159.

Mancewicz, Aneta. 2014. Intermedial Shakespeares on European stages. Basingstoke: Palgrave.

Mancewicz, Aneta. 2015. Review of Titus Andronicus (Teatr Polski) by Jan Klata. ReviewingShakespeare. http://bloggingshakespeare.com/reviewing-shakespeare/titus-andronicus-teatrpolski-teatr-wybrzeze-gdansk-shakespeare-festival-poland/ (accessed 12 April 2015).

Müller, Heiner. 2000a. Makbet, Hamletmaszyna, Anatomia Tytusa. Transl. Jacek St. Buras, Elżbieta Jeleń \& Monika Muskała. Kraków: Księgarnia Akademicka.

Müller, Heiner. 2000b. Hamletmachine. Transl. Carl Weber. In Daniel Fischlin \& Mark Fortier (eds.), Adaptations of Shakespeare. A critical anthology of plays from the seventeenth century to the present, 208-214. London \& New York: Routledge.

Mrozek, Witold. 2012. Titus Andronicus Jana Klaty. Szekspir a bombardowanie Drezna [Jan Klata's Titus Andronicus. Shakespeare and the bombing of Dresden]. Gazeta Wyborcza (18 September 2012). http://wyborcza.pl/1,75475,12503159.html (accessed 10 April 2015).

Schreiber, Paweł. 2012. Theatre and emigration: Catherine Grosvenor's and Lorne Campbell's Cherry Blossom. In Magdalena Cieślak \& Agnieszka Rasmus (eds.), Against and beyond: Subversion and transgression in mass media, popular culture and performance, 92-101. Newcastle upon Tyne: Cambridge Scholars Publishing. 